\title{
HOOLIGAN: BARCLAYS PREMIER LEAGUE: A CULTURAL DISCOURSE ANALYSIS
}

\author{
Bagus Indro Nugroho, Sigit Ricahyono \\ The Department of English Teaching \\ Faculty of Letters and Arts Education IKIP PGRI Madiun \\ bagus.indro.nugroho@gmail.com,ricahyono@yahoo.com
}

\begin{abstract}
Culture or history of each club in Barclays Premiere League and its hooligan influence the name of hooligan. The purposes of this study is identifying linguistics form of the Hooligan Firm's name in football club of Barclays Premiere League and is analyzing how the socio-cultural contexts relates to the Hooligan Firm's name in football club of Barclays Premiere League. This research uses Cultural Discourse Analysis (CuDA) as the grand design of analytical framework. CuDA concerns with analyzing of the impact of the culture to language. The type of qualitative method for this research are content analysis and documentation is used to collect the data. The results of this research shows the linguistic forms of Hooligan Firm's name are constructed by words, leading to nouns by inflectional and derivational suffixes, and phrases, leading to Head and Modifier. The cultural background of Hooligan Firm's name comes from the nickname of the club, the police rules, and the social conditions of the members. It deals with the matter of masculinity to get power among others.
\end{abstract}

Keywords : Hooligan, Hooligan Firm's name, Barclays Premier League, Cultural Discourse Analysis

\section{Introduction}

Culture deals with combination of knowledge, ideas, art, law, morals, customs, and any habits acquired by human or community as a member of a particular culture. It represents in language used such as naming. One of the naming culture which attract the researcher is the names of supporter firm of European football in Barclays Premier League. It is an English professional league for association football clubs. It is the England's primary football competition. It operates on a system of promotion and relegation with the Football League and is contested by 20 clubs. In that moment, the name of the football club, logo or symbol, and supporter's firm name are evidences the work of culture. There are choices on doing research upon those facts but supporter's name is more interesting to investigate because it relates to fans around the world.

Fans are important part of football. They make their identity through the creating eye-catching names, bringing scarf, wearing jersey, waving flags, rhythmic clapping, and singing or chanting with choreographies. In 
short, there is something unique with their special culture. Fans are also seen as fanatics who are interfering with the club's agenda, damaging its reputation, and causing troubles with authorities. The researcher observes that the name of the fan's club of European football are vary. In Italy it is known as Ultras, in Argentina known as Barra Brava, in Germany, Dutch and England known as Hooligan. Among them English hooligan has the highest reputation. It consists of 10 firm's names. The existence of hooligan in England are recognized by the other fans outside England. Therefore, English hooligan firm's name is the choice as the object material of this research.

Hooligan has a nickname as "English Disease". The choice word of "English Disease" comes to the researcher's mind to keep the curiosity why it should be that words. Besides, the construction of the name by hooligan pays attention to be analyzed. The background of creating the names will be followed by the culture of its followers. It would be challenging to do analyses within. For that reason, the research focuses on England hooligan. How come both culture and hooligans firm's name in Barclays Premier League merge one in another is an interesting topic to study.

\section{Method}

This research uses qualitative research. It is a method to investigate social phenomena in the world of football club then interpret it into a largely description on cultural data. The researcher analyzes the text through describe it into clearly analysis formation in linguistics course. In order to analyze the text, so the researcher uses qualitative content analysis as appropriate research design. Zhang and Wildemuth (1966: 1) state that qualitative content analysis is about analysis the word through text then examines its meaning, theme and pattern. It also allows this research to view social and cultural data. There are two types of source in this research; they are primary source and secondary source. An article from College of Charleston Libraries (2011) states that primary source of data is a document or physical object that is used to main object to be analyzed in the research, while secondary source is materials that is used to interpretations, explanations, and descriptions of primary sources. In this research, the ten of hooligan firm's names in Barclays Premier League as primary sources. While secondary sources are taken from books, articles and journals that is related to cultural reflection of hooligan firm's name in Barclays Premier League and also cultural discourse analysis. This research uses documentation to collect data as McCulloch (2004: 1) states that the researcher must understand about the documents related to the main of the study in order to minimize errors in understanding the context of text. 


\section{Result}

The types of language expressions in Hooligan Firm's name consist of words. Some of them use only one word and the others have a structure as phrase. The reseacher describes a Hooligan Firm's name by using morphological and syntactic structure. Carstairs and McCharty (2002: 16) state that morphemes is the smaller parts of words. The morphological pattern is used to analyze all of them to know the morpheme. Furthermore, the morphemes can be divided into the stem and the suffixes attached on the word. In research findings, all of the hooligan firm's names consists of word. Moreover, The two kinds of suffix are often used in Hooligan Firm's Name. Inflectional Suffix $-s$ is mostly used by some of Hooligan Firm's Names such as : HeadHunter-s, Urchin-s, Gooner-s, Scally $-s$ (Scallies), Guvnor-s, Zulu Warrior-s. It has functions to change single noun to plural noun. Furthermore, inflectional suffix $-\mathrm{s}$ in their name is used to show that it is organized by more than one supporters. In other way, there are derivational suffix which is used by some of it such as : Headhunt(er)s and Goon(er)s. The derivational suffix -er has a function to change verb, adjective, etc to a noun. Both of them use derivational suffix $-e r$.

Instead of word's formation, there also phrases to construct the firm's name. It needs Francis' (1958: 291) that the minimal structure that can be analyzed by chinese boxes is structure which consists of more than one lexical word. It is a phrase. So, the researcher uses a chinese boxes diagram to analyze the hooligan firm's names which are phrase. The seven phrases of hooligan's firm names are such as : HeadHunters, Red Army, Villa Hardcore, County Road Cutters, Section Five, Inter City Firm, Zulu Warriors. Those are dominated by structure of modification which consists of Head and Modifier. Modifier has a function to broaden, qualify, select, change, describe, or in some other way affect the meaning of head. In this cases, the modifier which is modified a head in the seven of Hooligan Firm's names has a function to describe further about the head.

\section{Discussion}

The next discussion is about how socio-cultural contexts relate to hooligan firm's names. It must be created based on culture, social, and history behind. It happens to the hooligan firm's name in football club of Barclays Premiere League. It needs the analysis by cultural discourse analysis. Those are three approaches of $\mathrm{CuDa}$ (Cultural Discourse Analysis) according to Carbaugh (1989: 45), they are; 1) The linguistic resources people use in context, not just grammar in the traditional sense, but the socially situated uses and meanings of words, their relations, and sequential forms of expression, 2) The various media used when communicating, and their comparative analysis, such as online "messaging" and how 
it compares to face-to-face messaging, and 3) The way verbal and nonverbal signs create and reveal social codes of identity, relationships, emotions, place, and communication itself. Thus, $\mathrm{CuDA}$ is one of discourse analysis types that concerns with social, culture and history of the phenomena that relates it to the text or talk so the researcher can understand the ideology or meaning behind the text or talk. This theory is used to analyze how sociocultural contexts relate to the Hooligans Firm's Name. It is as follows.

\section{Headhunters from Chelsea FC}

Chelsea FC has a hooligan firm as 'Headhunters'. The Headhunters is a Chelsea FC hardcore supporters which defend the Chelsea FC until they die. It began in late 1960s when football hooliganism existed. It started from the 'Chelsea Shed Boy' changed their name as 'The Chelsea Headhunters'. The investigation says, Macyntire found that the Chelsea Headhunters is a branch of Combat 18. An article by Lowles who interviews Darren Walls, ex-member of Combat 18, speaks out about the organization. Combat 18 is organization as fundamentally neo-nazi. Its principles is based on facism. Combat 18 takes its name from the first and eighth letters of the alphabet - A and $\mathrm{H}$, the initials for Adolf Hitler. Throughout the 1990's Combat 18 was associated with acts of terrorism and violence including arson attacks. Marriner (2009: -) wrote a book which described about Macintyre's investigation. He took a voice record of Gary Gable, the editor of Searchlight who is sent a postcard from the Combat 18 which is led by Andy Frain.

Based on the statement above, the name Headhunters is taken by a socio-cultural which is based on by a Combat 18 characteristics; Neo-Nazi, Facism, higher level violence, damage, and terrorism. Furthermore, the word "Headhunters" comes from Combat 18 organization which concerns with NeoNazi. Neo-Nazi attacked whoever his enemy was. Neo-Nazi will destroy or strike everyone who has no similar ideology with them. It inspires Headhunter to do the same thing as Neo-Nazi. Even though, the Headhunters more concern in football hooliganism but they also attack the people outside the football hooliganism. In recent days, The Headhunters becomes the one of branch organization of Combat 18. The word "Head" can be called as a people or their enemies and the word "Hunters" can be called as the members. The word 'Headhunters' can be called such a job which hunts and attacks the people who is considered as their enemy; another hooligan firm or the people outside the member of another hooligan firm.

2. Urchins from Liverpool FC

Liverpool FC was formed in 1892. The fanatic supporters from Liverpool usually called as Urchins. Bedford-Strohm, Frommam 
and Heuring et. al (2013 : 24) state that "In December 2003, a 15-year old boy from Liverpool went to see his first Merseyside Derby. It was also the first time ever he was in 'The Kop'. He was with his best friend. His best friend was an Urchin. One of the Hooligan from Liverpool FC . " In addition, according to William (2010: -) :

The Review reminded its readers that Liverpool was an impoverished city full of 'ragged urchins and neglected 'offal', a place where 'children of the gutter huddle together hungry and unwashed. ... The city, it was claimed locally, was invaded in 1892 by 'habitual drunks, indigent paupers from foreign lands and 'stowaway sailors'.

It says the name 'Urchins' is taken from the socio-cultural of Liverpool city. As a dockland, Liverpool has a popularity of middle-working class people. Liverpool is one of the cities which has the biggest population of urchins. The name 'Urchins' represents the social situation in Liverpool. The football club influences the local people to be a supporter. The Liverpool FC is supported mostly by the urchins. In addition, the word 'Urchins' is a trademark of Liverpool. Drugs and getting drunk become the characteristics of the people in Liverpool. So, the 'Urchins' is used as the identity of Hooligan Firm's Name from Liverpool FC. It is completed by the characters have been had; Drunkard and Fighter.
3. Red Army from Manchester United FC

The Red Army is the hooligan firm of Manchester United FC. Manchester United FC is one of big club in Barclays Premier League. Manchester United FC has a nickname as "The Red Devil". It is taken from symbol in the middle of the logo. In the 1960s word "The Red Devil" existed in club program and scarves. Dunning, Murphy, and William et. al. (2014: -) state that "This was one of the earliest publicized events in the rise of Manchester United fans- of the so- called "Red Army"- to a position of supremacy among the country's football hooligans."

Based on statement, the color 'Red' identically is related to Manchester United. It begins from the nickname of the club as "The Red Devil'. The nickname 'The Red Devil' is taken from the abstract symbol in the middle of the logo from the club. After the nickname exists, the kit changes into dominant with red color. So, The color 'Red' influences the name of the Hooligan Firm from Manchester United FC. It is called 'Red Army'. Nowadays, The 'Red Army' is not only used by hooligan firm. All of the supporter of Manchester United FC usually called as 'United Red Army'. The 'Red' word in 'Red Army' can be called as the football club which is supported by the member, Manchester United FC which is marked by 'Red' color. 
In other ways, The word 'Army' can be called as the members of the hooligan firm itself.

4. Gooners from Arsenal FC

Arsenal Football Club is a Londonbased association football team that competes in the Barclays Premier League. Formed in 1886 in Woolwich by the workers of an armaments factory, the club's original name was Dial Square, which was later changed into Royal Arsenal and eventually evolved into its current form. The club has a large canon on its symbol, and its nickname is the Gunners both of which owe everything to the club founders' association with the British army. The Gooners were known as a violent football hooligan firm, who were mainly active within the 1980s. However nowadays the name is mainly used by the majority of Arsenal supporters (the non-hooligan sector) who consider themselves to be die hard Arsenal supporters.

Based on the data, the name 'Gooners' is taken by a nickname of the club, The Gunners. The nickname itself is made by the founders who the people inside are from association of British Army. It is a clever variation type of words. In the pronunciation, it is as similar as Gunners which is a nickname of Arsenal FC. 'Gooners' is a variation word which is by the member. They want to show the identity and characteristic in one way. The identity means that the members are the die hard supporter of Arsenal FC which has a nickname 'Gunners'. The word 'Gunners' is taken from the meaning of the club and the history of the founders. The characteristics means the common of the hooligan character; violence, damage, riot, and madness.

\section{Villa Hardcore from Aston Villa FC}

Aston Villa Hardcore (often shortened to Villa Hardcore) is a football hooligan firm associated with the Premiere League club Aston Villa, based in Birmingham, England. The firm have been active since 1993. The Hardcore has been involved in some highprofile hooligan fights in Europe, while following Villa and England. The firm still exists today, but, like all hooligan firms, they have been marginalized. The Hardcore has clashed a number of times with city and fierce rivals, the Birmingham Zulus, associated with Aston Villa's fiercest rivals. Lutwyche and Fowler ( 2008 : - ) state that "We are Villa 'Hardcore', Aston Villa Football Club's hardcore support. We are football hooligans. Thugs, yobs, scum, hooligans, whatever labels you, the police and the press have seen fit to attach us." It means that the members of Villa Hardcore clearly admit that they the one of hooligan firm in England. Evermore, they say that they have a bad attitude which become a trademark for them.

Furthermore, according to Lutwyche and Fowler (2008:-), Steven Fowler, the leader of Villa Hardcore Hooligan Firm has 
been identified by the police as 'Hardcore' Category C supporter. The word 'Villa' which has a meaning as identity which the members of 'Aston Villa FC' supporters. Furthermore, the word 'Hardcore' is identity. In other way, it shows that they are extreme supporters football club. So, the 'Villa Hardcore' is the hooligan firm which the members supports the Aston Villa FC. They do not only attend and watch the match but also they come with a reason to causing a problem.

\section{County Road Cutters from Everton FC}

The hooligan firm of Everton FC is known as County Road Cutters. The County Road Cutters were, at their peak throughout the 1980s and early 1990s, one of the largest hooliganism firms in England. Their name derives from County Road, the long road leading up to Everton's home ground, Goodison Park, in Walton, Liverpool, and also from the firm's use of Stanley knives in fights with other hooligan firms. Jennings (2009:36) states that "We sang our way down County Road, and we sang our way all the way into the ground, and we sang long before kick off." It means that, before the match in Goodison Park the Everton FC supporter always walk in County Road where the Goodison Park is built. In addition Nicholls in Reijnders, Zwaan, Duits (2014:296) state that "[O]ne of my hardest decisious was over a section in Scally about a gang called the County Road Cutters who are specialists in knife attacks. This story was told to the author." It says that The 'County Road Cutters' becomes the characteristic, trademark, and identity of Everton FC Hooligan Firm members. The 'County Road' shows that the members are supporters of Everton FC. The 'Cutters' shows how they fight. The members always bring a knife on their hand. It becomes a characteristic of the members.

\section{Section 5 from West Brom Albion}

The hardline supporters or usually called as hooligan firm of Westbrom Albion FC is Section 5. According to Webley (2013:6-7) "For Section Five it had now become very serious. Their firm had split up and gone off in different directions; for those being chased it was literally survival of the fittest." Section 5 originality is one of legislation by the police especially in hooliganism. It is the rule which is used by the police to handle hooligan. According to Howell and Harrington (2013: -) "Section 5 of the Public Order Act 1936 is particularly useful for dealing with hooligans as it provides adequate police power and reasonable punishment for offenders."

It states the name of Section 5 is the one of legislation in hooliganism. The content of Section 5 is about how the police power to give feedback and punishment to the members of hooligan who are indicated as a disturbers or offenders in public area. The name 'Section $5^{\prime}$ is taken from legislation which is given by 
the police. Furthermore, the word 'Section 5' becomes the identity of the members of West Brom Albion hooligan. The members are indicated by the police as trouble makers. Based on the indication, the members use the legislation to their identity for their firm; West Brom Albion Section 5. It means the members of hooligans indicated as offenders.

\section{Inter-City Firm from West Ham United}

The nickname 'Hammers' is used for the name of supporters of West Ham United. In other way, the hardline supporters of West Ham United usually called as Inter-City Firm. According to Ireland (2009: -) :

The Inter-City Firm were one of the first 'casuals', so called because they avoided police supervision by not wearing football-related clothing and travelled to away matches on regular 'Inter-City' trains rather than on the cheap and more tightly-policed 'football special' charter trains. The group were an infamous West Ham aligned gang.

The name 'Inter-City' is taken from the sociocultural of the members. The originality of 'Inter-City' is the name of service train railway services. It is express passenger train services that cover longer distances than commuter or regional trains. The members of the West Ham United hooligan use this transportation to go to the West Ham United away matches in another cities. The price of this transportation is cheaper than the other. Furthermore, the members use this transportation to avoid the police. The name
'Inter-City' is reflection of transportation name which usually use by the members. This habitual is seen by another hooligans and finally becomes the identity and trademark for West Ham United hooligan.

9. Guvnors from Manchester City

The hooligan firm which support the Manchester City FC is called 'Guvnors'. According to Guilianotti (2013:203) "The following month, April 1988, 26, Manchester City fans were arrested at down by 100 officers after six-month undercover operation entitled Operation Omega. The group was name The Young Guvnors, calling cards were found as were knives, coshes, and body armor “ Based on Andrews' (2004:175), “A few weeks later and United are playing City at Old Trafford, with City on the point of relegation. ... As eyes focus, a banner is visible flying behind the plane reading 'MCFC - REAL CLUB REAL FANS'." Those statements clearly shows that as supporters who support the city football club becomes a local pride. In this case, the Man City hooligan 'Guvnors' feels that they are local people of Manchester which support a real club from Manchester. They consider that they are the boss (as a local people) because of the rivals Manchester United supporter come from outside of Manchester. The word 'Guvnors' is taken from socio-cultural which is risen by an ideology as a local people. The members of 'Guvnors' believe that an authentic football 
club from Manchester is Manchester City. As a Mancuian (a local people of Manchester) it is a duty to support the local and authentic football club from Manchester such as Manchester City. It is reinforced when the rivals club; Manchester United is supported by supporter outside of Manchester. This reason make the members as a local people or a real Mancuian feels like a boss. So, they use a British slang 'Guvnors' to say that they are the boss, the real Mancuian.

\section{Zulu Warriors from Birmingham City}

Birmingham City has supporters and the hooligan firm. The hooligan firm from Birmingham City becomes one of dangerous football hooligans. The hooligan firm from Birmingham City is usually called as Zulu Warriors. According to Guilianotti (2013:200), "Operation Red Card ended in January 1987 when 180 police officers swooped into the homes of 67 youths suspected of belonging to a hooligan group called 'Zulu Warriors', supporters of Birmingham City." In addition, Webley (2013:20) states that "Birmingham city's firm is renowed for the black and white mix that exits and with a name like ZULU what can easy. Aston Villa firm on the other hand is the total opposite." The data shows the name of 'Zulu Warriors' is taken by a socio-cultural of the members. The members of Birmingham City football firm is dominated by African people or Blacks. Furthermore, another races or the Whites which also as the members give the respect to them. They do not care of racism. This is why they use 'Zulu' word to their name. In other word, it becomes the identity of the hooligan firm. The word 'Warriors' becomes the character of the members. They want to show that they have an attitude as same as the warriors in a war situation.

\section{Conclusion}

The linguistic forms of Hooligan Firm's name are constructed by words and phrases. Among them the words formation are usually inflectional suffix $-\mathrm{s}$ and derivational suffix $-r$. Those are nouns. The syntactical process show the firm's names consist of Head and Modifier where the modifier is as the supporting case to identify the Head. Meanwhile, CuDA works with the cultural data which indicates the nickname of the club, the police rules, and the social conditions of the members. The meaning reveals that those fans are furious because it will make them powerful and undefeated. All are about masculinity matters. The members use the name to show their identity and characteristics. In addition, the name also becomes a trademark which is easily recognized by another hooligan firm and common people. 


\section{Acknowledgements}

The researcher would like to thank to Drs. Dwi Setyadi, M.M. and Sigit Ricahyono, S.S., M.Pd. as advisors for the comments, suggestions, and revisions in the content of this research. The researscher also would like to thank to Lusia Kristiasih Dwi P., S.S., M.A. for any revisions and discussions.

\section{References}

Andrews, David L. 2004. Manchester United: A Thematic Study. London: Routledge.

Bedford-Strhom, Nathan.; Frommann, Hanne; Heuring, Horst,.et al. 2013. Short Stories: Eine Sammlung von Kurzgeschichten. Hamburg: BoDBooks On Demand

Carbaugh, Donal. 2008. Cultural Discourse Analysis: Communication Practices and Intercultural Encounters. University of Massachusetts - Amherst from

http://works.bepress.com/donal_carbau $\mathrm{gh} / 11$

Carbaugh, Donal. 2009. Putting Policy in its Place through Cultural Discourse Analysis. University of Massachusetts - Amherst from http://works.bepress.com/donal_carbau $\mathrm{gh} / 22$

Carstairs, Andrew and McCharty. 2002. An Introduction to English Morphology: Words and Their Structure. Edinburgh: Edinburgh University Press Ltd

College of Charleston libraries. 2011. What's the difference between primary and secondary sources? Accessed on $23^{\text {rd }}$ November 2014 from http://answers.library.cofc.edu/a.php?q $\mathrm{id}=78940$.

Dunning, Eric., Murphy, Patrick J., Williams, John. 2014. The Roots of Football Hooliganism (RLE Sports Studies): An Historical and Sociological Study. London:Routledge.

Francis, W. Nelson. 1958. The Structure of American English. New York: The Ronald Press Company.

Guilianotti, Richard. 2013. Football, Violence, and Social Identity. London: Routledge.

Howell, Dennis., Harrington, J.A. 2013. Soccer Hooliganism : A Preminilary Report. Amsterdam: Elsevier.

Ireland, Nick. 2009. The Popondetta Butterfly. Milton Keynes : Worclay.

Jennings, Joe. 2009. Ever the Optimist. Raleigh: Lulu

Luwytche, Michel., Fowler, Steven Patrick. 2008. Hardcore. Birmingham:VHC Publishing.

Marriner, Jason. 2011. Life as a Chelsea Headhunter. Essex: Apex Publishing Ltd.

McCulloch, Gary. 2004. Documentary Research in Education, History and Social Science. New York: Routledge Falmer

Reijnders, Stijn; Zwaan, Koos; Duits, Linda. 2014. The Ashgate Research Companion to Fan Cultures. Farnham: Ashgate Publishing, Ltd.

Thomas, David R. 2006. “A General Inductive Approach for Analyzing Qualitative Evaluation Data". American Journal of 
Evaluation, Vol. 27 No. 2, June 2006 pp. 237-246

William, John. 2010. Red Men : Liverpool Football Club - The Biography. Edinburgh: Mainstream Publishing; First Edition.

Webley, Elvis. 2013. Hooligans, Doormen, and the Ten - Metre Walk. Indiana: Balboa Press.
Zhang, Yan and Wildemuth, Barbara M. 1966. Qualitative Analysis of Content. Accessed on $19^{\text {th }}$ October 2014 from

https://www.ischool.utexas.edu/ yanz/ Content_analysis.pdf 